\title{
ЛІТЕРАТУРОЗНАВСТВО
}

\author{
Айдачич Д. \\ д.ф.н., проф., Белградський університет (Республіка Сербія) \\ Ajdačić D. \\ Doctor Hab., Professor, University of Belgrade (Republic of Serbia) \\ ІРОНІЯ ТА ФАНТАСТИКА
}

\section{IRONY AND FANTASY}

Відсутність типології іронії в теорії фантастики випливає з того, щуо іронія та фантастика по-різному формують і перетворюють реальність - фантастика $\epsilon$ видом фікиійного зображування дивовижних світів чи явищ. Навпаки, іронія не створює світів; в ній суб'єкт коментує реальність, додаючи інше бачення, бачення із переоцінкою та відхиленням від сказаного чи представленого. Іронія може коментувати реалії різного онтологічного статусу, тобто, іронія може стосуватися реального світу та вигаданого світу, незважаючи на те, чи він справжній чи дивовижний. Фантазія перетворює світ - викривлює, руйнує чи добудовує, або будує нові світи, а іронія вже до представлених ідей та поглядів додає інше бачення, незалежно від того, реальні вони чи вигадані.

У тексті обговорюються термінологічні та літературно-теоретичні аспекти використання іронії у творах худоньої літератури. Книга Драгана Стояновича "Іронія та значення" використовується як теоретична відправна точка. Після висвітлення дотиків іронії та вигадки та їх особливих якостей та ролей пропонується типологія використання іроніі у художній літературі, яка відокремлює іронічні дії, щуо стосуються реального світу, дивовижного світу та проблематизує взаємозв'язок між реальним та дивовижним світом.

Ключові слова: іронія, фантастика, алегорія, теорія літератури.

The absence of a typology of irony in the theory of fiction stems from the fact that irony and fiction differently form and transform reality - fiction is a kind of fictional depiction of amazing worlds or phenomena. On the contrary, irony does not create worlds; in it, the 
subject comments on reality, adding another vision, a vision with a reassessment and deviation from what is said or presented. Irony can comment on the realities of different ontological status, that is, irony can relate to the real world and the fictional world, whether it is real or amazing. Fantasy transforms the world - it distorts, destroys or completes, or builds new worlds, and irony already adds a different vision to the ideas and views presented, regardless of whether they are real or fictional.

The terminological and literary-theoretical aspects of the use of irony in works of literary fiction are discussed in the text. Dragan Stojanović's book "Irony and Meaning" and the author's terms "Ironical Focus" and "Meaning Pressure" are used as a theoretical starting point. After highlighting the touchpoints of irony and fiction and their special qualities and roles, is proposed a typology of the use of irony in fiction that separates ironic actions concerning the real world, the marvelous world and problematizing the relationship between the real and the marvelous world.

Key words: irony, fantastic fiction, allegory, literature theory.

Іронія та (по)сміх. Різні типи сміху виражають різні почуття - весела посмішка та незлобивий жарт висловлюють життєрадісні почуття, а погані жарти чи насмішка 3 наругою та виражають ненависть або відсутність співчуття. Слов'янські мови у визначеннях різновидів сміху в особистих стосунках пропонують багато слів та образно нюансованих слів та виразів, але, віддаляючись від сфери переживань і наближаючись до абстрактних понять, які стосуються мистецтва, кількість слів слов'янського походження зменшується, а кількість запозичень 3 інших мов збільшується. У дослідженнях літератури гумористичні аспекти часто описуються словами 3 давньогрецької чи латинської мов. Ці назви також вказують на різне емоційне ставлення до світу та до людей. Між ними мало сематично нейтральних термінів, як 'гумор', 'комізм' та 'каламбур', а порівняно більше термінів, які зі сміхом підкреслюють вади світу 'гротеск', 'іронія', ‘сарказм', ‘сатира', 'цинізм', або літературознавчих термінів, що вказують на жартивливі обробки художніх творів ‘бурлеск', 'пародія’ та 'травестія'. Хоча більшість цих термінів визначена ще у античній риториці та поетиці, а пізніше доповнена в посібниках 3 класицистичної та сучасної літературної теорії, часто не існує 
термінологічної точності в інтерпретаціях фантастичної літератури. Терміни, гумор, сатира та пародія набули занадто пирокого значення та взаємно перегукуються. Семантично розпорошене та паралельне використання близькозначних понять, навіть коли, вони пов'язані 3 різними явищами, є свідченням недостатньо розчленованих типів гумору у фантастичній літературі. Незважаючи на численні дискусії естетиків, стилістів та теоретиків літератури про смішне, тільки про фантастичні аспекти гротеску присвячено більше праць фундаментального значення. А твори Лукіана, Раблеа, Гофмана, Булгакова, Пекіча, Лема та інших чудодійників веселих чудес, безумовно, заслуговують на більш точні визначення їх вминя поєднувати смішне і дивне.

Якщо йдеться про іронію, я не знаю жодної типології іронічного образотворення у творах літературної фантастики. Розмежування окремих видів іронії у фантастиці також вказувало б на відмінні риси та їх ролі, дозволило б точніше зрозуміти та описати фантастичний дискурс у фикційних текстах та зробило більш очевидними механізми використання іронічних насмішок над світом. 3 точки зору історії літератури, така типологія була б корисною в історичній поетиці різних епох, в поетиці жанрів фантастики, а також в авторській поетиці 3 елементами поетики епох і жанрів.

Відсутність типології іронії в теорії фантастики випливає 3 того, що іронія та фантастика по-різному формують і перетворюють реальність фантастика $є$ видом фікційного зображування дивовижних світів чи явищ. Навпаки, іронія не створює світів; в ній суб'єкт коментує реальність, додаючи інше бачення, бачення із переоцінкою та відхиленням від сказаного чи представленого. Іронія може коментувати реалії різного онтологічного статусу, тобто, іронія може стосуватися реального світу та вигаданого світу, незважаючи на те, чи він справжній чи дивовижний. Фантазія перетворює світ - викривлює, руйнує чи добудовує, або будує нові світи, а іронія вже до представлених ідей та поглядів додає інше 
бачення, незалежно від того, реальні вони чи вигадані.

Іронія в античній поетиці вважалася ріторичною фігурою, тоді як «іронія софістів», «сокративська іронія» визначалася як глузування 3 твердженям співрозмовника в вмінні переконання що його погляді неправильні чи суперечливі. На межі 18-19 століть поняття «художньої іронії» німецького естетика Фрідріха Шлегеля [Struc' 1998: 37-39] значно розширило значення іронії, яку потім названо «романтичною іронією». Ця сполука часто використовувалася в 19 столітті, але вона не усталилася, оскільки романтизм, що розумівся як часова епоха європейського мистецтва першої половини 19 століття, позбавляв у висловленні «романтична іронія» прикметника «романтична» типологічних рис у розумінні Шлегеля. Певне повернення до давнього поняття іронії як ріторичної фігури було розігране в 19 столітті в термінах «іронія історії» (Гегель), «іронія долі», в яких було розширене значення. У обох випадках існує суперечність між високими цілями та непропорційно поганими результатами, між ідеалами та банальною реальністю, тому іронія пов'язана з порушенням ілюзій.

Володимир Янкелевич метафорично описує дію іронії як підпорядування «головокружінню, викликане двоозначністю» [Jankelevič 1989: 129]. У ситуації, коли проявляється іронія, справді існує неоднозначність, але метафора Янкелевича не виправдана, враховуючи однозначну точку зору іроніста. Двозначність не існує ні для учасників спілкування, які не впізнають іронії, ні для людини, слова чи дії, якої піддаються іронії. Іронія, тобто, іронічний коментар до заяви чи вчинку не заперечує сказане чи зроблене - але підриває деякі їх риси, завдяки чому іроніст пропонує слухачеві розділити його судження.

Драган Стоянович виходить з феноменологічної теорії розуміння та інтерпретації літературних текстів польського філософа Романа Інгардена і вказує, що «іронія існує, коли контекст чинить такий тиск на значення і на розуміння тексту, що він залишає лінію, визначену смисловими 
одиницями» [Stojanović 1984: 141], і це чинить контекстний «смисловий тиск». Під ударом іронічного підриву найчастіше опиняються цінності, обгрунтовані значенням або призначенням. Цінність часто поєднується 3 деякою властивістю змісту тексту або самим існуванням цього змісту. Ось чому іронічні ефекти часто супроводжуються сміхом, який пов'язаний із детронізацією цінностей [Stojanović 1984: 149].

Драган Стоянович проваджує в книзі про іронію термін «іронічний фокус» [Stojanović 1984: 150] посилаючись на обмежену частину тексту, де діє іронія, але додає, що в одному тексті може бути і більше одного «іронічного фокусу». Коли учасник спілкування пізнає «семантичний тиск», що чиниться в «іронічних фокусах», він усвідомлює два значення, дві точки зору стосовно сказаного або зробленого. Типи відхилень, спричинених «семантичним тиском» в іронічному до-окресленні, не можуть бути охоплені та систематизовані, оскільки ситуації, в яких іронія може активізуватися, незліченні. Але предметом теоретичного опрацювання може бути функція семантичного тиску іронії щодо реальних або вигаданих реалій.

Іронія та фантастика. Іронія, як процес підривання сенсу шляхом додавання різної цінності чи знань, в текстах літературної фантастики також може іронічно додатково означити статус реальності. Ось чому важливо помітити, чи у фантастичному тексті іронічні фокуси стосуються реального, чи нереального світу, чи вони проблематизують існування іншого світу. У творах фантастики іронічна модифікація зображеного, із введенням підозри чи спростування може формувати різні чинники тексту. В деяких випадках іронія стосується реалій реальноого світу, що не мають нічого спільного 3 дивовижним, в інших - стосується дивовижного та реального в літературних уявленнях про світ, а в інших - стосується лише дивовижного. Тому потрібно розділити іронію в фантастици на 1) іронію у зображені реального, нефантастичного світу в фантастичному тексті, 2) в зображенні дивовижного світу, який не торкається співвідношення 
дивовижного i реального, і в пародіях фантазії, 3) в проблематизації відношення між дивовижним і реальним у літературно зображенному світі.

1. Іронія в тексті фантастики, яка не проблематизує взаємозв'язок між реальним та світом фантастичним. Коли іронія стосується лише реального чи лише дивовижного світу, не виникає сумнівів щодо онтологічного статусу представлених реалій, немає коливання щодо існування чи неіснування представленого світу, а іронічний сенс висвітлює стосунки всередині одного із світів. Без перетинання межі між дивовижним та реальним, іронії можуть піддаватися різні релігійні, ідеологічні, психологічні та ін. погляди акторів, прогалини між бажаннями та можливостями, вміннями та знаннями. Іронічною насмішкою виявляється незгода, помичання відсутності чиїхось знань чи вмінь, або нестача здібностей, іронія також торкається певного недоліку в ідентифікації чи самоідентифікації дійових осіб у вигаданому світі.

2.1. Іронія у фантастичних алегоріях схрещених світів. Дивовижні та реальні світи можуть переплітатися в літературних творах, а можуть перетинатися також різні дивовижні світи 3 алегоричним зв'язком цих світів. Такий погляд не грунтується на концепції фантастики за визначенням Цветана Тодорова. Фантастичні алегорії, засновані на злитті та перетині двох світів, можна назвати фантастичними алегоричними дуотопіями. Воне виявляють, що не існує такої великої різниці між схрещеними світами. Прикметник «алегорична» вказує на те, що автор спонукає читача до сприйняття спорідненості між пов'язаними світами та розуміння принципу, що їх пов'язує як алегоричну рамку в розумінні тексту. Подвійність іронії досягається переплетенням одного реального, впізнаваного людиною світу 3 фантазією, добудованим міфологічно впізнаваним чи вигаданим світом. Поєднуючи реальний і світ фантазії, стають можливими сатиричні алюзії та алегорії.

У літературних зображеннях людей та нелюдських істот - демонів, монстрів, богів, прибульців чи розлючених машин - застосовують стратегії сміху, що зменшують відмінності між людьми та нелюдами. Таким чином, 
нелюди з страшних розповідей перестають бути небезпечними, абсолютно чужими і набувають деяких людських рис. У тексті «Пародія та сатира в зображенні демонів у слов'янських літературах 19 століття» я зазначив вигадане зображення чортів, які, як і люди, є бюрократами, вишуканими та брехливо вишуканими або закоханими [Ajdačić 2015]. Хоча я використовував терміни пародія, безумовно, іронія має своє місце у фигуративному схрещуванні світів.

2.2. Дивовижні світи та іронія перевернутого оцінювання. Коли щось дуже варте оцінюється як нікчемне, і навпаки, коли вихваляєтся то, що слід осуджувати, а оскаржується то, що слід хвалити, коли виражається незгода 3 порушенням принципів етичної доцільності, можна використовувати іронію. Знавець літератури російського романтизму Юрій Манн, дивлячись на взаємозв'язок двох планів у драмі Іжорський В. Кюхельбекера, зауважує, що людський план там не підпорякувується вишому плану а навпаки: «Світ іронії проникає у царину романтичної двоплощиності» (Mann 2007: 408). У цьому творі повністю замінені етичні ролі диявола і людини. У романі Б. Пекіча Час чудес євангельська історія перетворюється у ремітологізовану ренаррацію, в який Христові чудеса приносять лише нещастя. Окрім фантастики перевертання людських та нелюдських світів, переворот 3 іронічним переосмисленням може відбуватися - на часовій осі - світів минулого та майбутнього, минулого та сьогодення, на осі емоцій чуттєвого та нечуттєвого світу тощо. Спекулятивно уявляючи правила чи передумови світу, що знаходиться в іншому місці, письменникифантасті схільні до іронії можуть створити рамки для цілого ряду іронічних фокусів та ефектів.

У сатиричній фантастиці перетворення світу часто піддається деякій систематично реалізованій образній процедурі, тому іронія тісно пов'язана 3 алегорією, системною метафорою, гіперболою тощо. Сатири, в яких 
використовується фантастика, часто грунтуються або на перетині світів, або на перевороту ціностей.

2.3. Іронія та пародії фантастики. Використання іронії в тексті 3 багатьма іронічними фокусами, що систематично діють в усьому тексті, відбувається в пародіях. Хоча метод використання іронії в реалізації принципу сміху дещо інший, іронія в обох випадках охоплює низку реалій та поглядів. Нанизування «іронічних фокусів» збіраються іронічні ефекти як у творенню так і в розумінні тексту.

Пародії фантастики можуть бути пародією на окремий авторський фантастичний текст, пародією на жанрові споріднені тексти, але також пародієо на усталені, стереотипні уявлення про дивовижний світ. У пародіюванні формаційні стилістичні та жанрові елементи (прото)тексту в тексті пародії використовуються як формальні елементи жанрового стилю та поетики (формули, усталені фігури, віршування тощо) або як елементи змісту та значення. Формальні елементи служать для ідентифікації жанру, тоді як лексичні елементи, а також способи представлення персонажів, дій та коментарів чинять смисловий тиск в іронічних фокусах і можуть викликати іронічний підрив та відхилення.

«Пародія - це нове змістовне освітлення цілого», пише Драган Стоянович:

Новостворене ціле нагадує старому, тим, що воно виникає внаслідок перебудови його складових елементів, але говорить нам про щось інше. Воно за значенням залежить від початкового цілого, зі своєю самобутньою будовою, але, вказуючи на цю залежність, іноді навіть вихваляючись 3 нею, вона хоче мати себе як незалежну і самодостатню. Як повторення 3 відмінностями, саме тому, що показує їх, вона високо себе оцінює. Іноді неможливо розрізнити, чи жартує вона таким чином із собою або з тим, що ій передувало, чи знущається над собою чи своїм джерелом; чи сумує вона за нею - добре видно знаючому оку - походження від чогось попереднього, або, навпаки, радіє їй [Stojanović 2018: 10].

Автор підкреслює складне відношення пародиста до взору пародії (чи 
знущається він над собою чи над своїм джерелом), що виникає внаслідок необхідного зв' язку двох текстів та двох авторів.

$€$ елементи пародії, наприклад формально стилістичні елементи тексту, яких не піддано іронічному відхиленню / тиску. Іронія використовується і там, де немає пародійного прототексту. Якщо мова йде про пародії фантастики, в іронічних фокусах, то змістовному тиску / іронічному відхиленню можуть бути піддані мотиви, способ зображення дивовижних істот, поетика жанру та введенням до нього іншого чужого дискурса, високої міметики в низькоміметичний дискурс, або навпаки.

Деякі дії пародійника, викликають сміх, посмішку чи спонукають читача задумуватися, - це перебільшення деяких елементів попередньої розповіді, придушення чогось іншого, різні викриття (не обов'язково карикатурні, іноді абсурдні чи заплутані, але просвітлююча в їх дивацтві), перехрестя з іншими смисловими частинами і змішування їх елементів, часто неспоріднених і по-різному орієнтованих за значенням [Stojanović 2018: 10].

Близькі стратегії сміху в літературі також дають можливість переплести пародію з іншими жанрами. Ідея Драгана Стояновича про перетин елементів пародії з іншими_різновидами смішного виникає у сполуках пародії та сатири, особливо у випадках, коли включаються алегоричні перетини світів чи навернення ціностей. У випадку таких літературних текстів слід також вказати на зв'язок між сатиричним та пародійним компонентами.

\section{1. Іронія як чинник зміни світогляду - раціонально підривання} забобонів. Іронія $є$ дискурсивним засобом сумніву в існуванні явищ які суперечать раціональному світогляду, а звідси також $є$ стратегією заперечування іраціональних ставлень чи суджень. Така іронія в літературному тексті опирається на здоровий глузд або на наукове розуміння речей і спрямоване на викликання невпевненості співрозмовника та на зміну його світогляду. Такі процедури можна назвати іронічним запереченням світоглядних переконаннь або іронічним переконанням. 
Якщо підозрюється, що істота чи явище не є чудодійним, оповідач може розгадати забобони без використання іронії. Але якщо оповідач припускає коментарями чи словами свого героя, що якогось чудовиська, нечистої сили, дива магії чи інших забобонів не існують, іронія підказує необхідність зміни точки зору пізнання. Іронія впливає на формування взаємозв'язку між реальним та дивовижним світом, ставить під сумнів онтологічні переконання та ставить під сумнів існування чи неіснування чогось. В іронічних текстах зміна світогляду, стратегій їх виявлення та розкриття, висвітлення та оскарження суперечностей, встановлення або розвіювання сумнівів пов'язане з проблемою істинного чи помилкового. 3 психологічної точки зору це може бути питання психології пізнання, що передбачає низку рис, починаючи від підозрілості до легковажності, від необізнаності до всезнання.

Іронія яка вживається у запереченні забобонних грунтується на висміюванні, чи спростуванні фальшивих знань героїв. Такий вид іронії спирається на насмишку, глузування та сатиру. Іронія спростування полягає у використанні заперечені поглядів героя чи читача оповідання.

Підвид спростування забобоннів представлений фантастичними текстами про шахрайство та шахраїв. У них письменник розкриває читачеві, як шахрай використовує забобони своєї жертви для отримання особистої вигоди. Використання іронії посилює враження розриву між двома баченнями реальності. Але фантастика, що супроводжується іронічними коментарями, також може стосуватися всезнаючих богів трикстерів (наприклад, скандинавські язичницький бог Локі), замаскованих богів, брехливих богів і магів.

3.2. Іронія у спростуванні раціональних сумнівів. У суперечки про існування потойбічних явищ чи істот, прихильник релігійних чи езотеричних знань може іронічно кинути виклик заступникам раціонального світогляду. 3 допомогою іронічних насмішок, він може доводити хибність раціонального світогляду та існування магічних навичок, дивовижних предметів чи здібностей, що виходять за ці межі реальності. 
Незважаючи на точність поетичних та літературно-теоретичних визначень аспектів сміху у літературних текстах, в тлумаченнях фантастики часто наявна неточність, що $є$ результатом неоднозначного використання термінів жартівливого, комічного, іронічного, пародійного, сатиричного та под. Іронія та фантастика належать до різних видів вираження, тому важко систематизувати їхні відношення. У тексті пропонується типологія взаємозв'язку іронії та фантастики, заснована на ролі іронії та іронічного відхилення / коментаря у зображенні світу - в представленому реальному світі, в дивовижному світі та в проблематизації взаємозв'язку між реальним та дивовижним світом. Цей нарис, у подальшому буде підкриплений інтерпретаціями конкретних творів слов'янської фантастичної літератури, що імовірно дозволить вдосконалити та уточнити запроплновані теоретічні положення.

\title{
REFERENCES:
}

1. Ajdačić D. (2015) Parodija i satira u prikazima demona u slovenskim književnostima 19. veka. In: Slov'jans'ka fantastika. Zbirnyk naukovyh prac, tom. 2. Red. Dejan Ajdačič, Kyiv, 2015, s. 7-24.

2. Jankelevič [Jankélévitch] V. (1989) Ironija, Sremski Karlovci.

3. Mann J. (2007) Russkaja literatura XIX veka. Epoha romantizma, Moskva, 2007.

4. Stojanović D. (2018) Svečani čas pripovesti. Josif i njegova braća, Beograd.

5. Stojanović D. (1984) Ironija i značenje, Beograd.

6. Struc' R. (1998) Riznovydy ironiji Naukovi zapysky NaUKMA. Filologija, Kyiv, tom 4, 37-42.

7. Żmigrodzka M. (2002) Ironia romantyczna, Stownik literatury polskiej XIX vieku, Red.

A. Kowalczykowa J. Bachórz, Warszawa.

Білик $\boldsymbol{H}$.

д.ф.н., доц., Київський національний університет імені Тараса Шевченка (Украӥна)

Bilyk N.

Doctor Hab., Associate Professor, Taras Shevchenko National University of

Kyiv (Ukraine)

\author{
ІНТЕРМЕДІАЛЬНІСТЬ ТА ЕКФРАЗИС \\ У РОМАНАХ М. ПАВИЧА
}

